\title{
POTÊNCIA DE AÇÃO E ORDEM: O PODER E A RAZÃO SEGỦNDO NICOLAU MAQUIAVEL E THOMAS HOBBES
}

Wolfgang Kersting*

RESUMO - O autor apresenta aborda, primeiramente, a relação entre poder e razão no pensamento político de Maquiavel. Num segundo momento, apresenta, no pensamento de Hobbes, a trajetória que se estende da razão impotente do estado de natureza até à razão poderosa do Estado, dispensador de segurança. PALAVRAS-CHAVE - Maquiavel. Hobbes. Poder. Razão.
ABSTRACT - The author analyses in a first moment the relationship between power and reason in the political thought of Machiavelli. In a second moment, he exposes, according to Hobbes's political philosophy, the path to be gone through from the powerless reason of the state of nature towards the powerful reason of the State, which grants security. KEY WORDS - Machiavelli. Hobbes. Power. Reason.

(1) A felicidade é conservadora e não quer mudanças. Ela desfruta a si mesma e quer que o instante plenificado dure para sempre. Por isso, segundo um conhecido dito de Hegel, nas folhas da história as páginas da felicidade estão vazias. Mas isso não se aplica apenas ao livro da história que registra os atos. Aplica-se também ao livro da história que registra as idéias, e nele, particularmente, aos capítulos que se ocupam do transcurso do pensamento político. O pensamento político nasceu na crise. Isso já se aplica a seu fundador, o sonhador sofocrático Platão, que queria trazer ordem e verdade, através da filosofia e da contemplação das idéias, a um mundo político corrupto, dominado por sofistas, demagogos e tiranos. Isso se aplica mais ainda ao pensamento político da Idade Moderna, que, em seus argumentos de legitimação da teoria do contrato, narra repetidas vezes a história da criação do Estado, do surgimento racionalmente controlado da ordem, a partir da anarquia e do caos. Entretanto, ao passo que Platão descreve o salvador filosófico como estranho sobrenatural e figura semelhante a Deus, que se aproxima, a partir de fora, da realidade humana atormentada por crises, a filosofia política da Idade Moderna assume a crise

* Professor de Filosofia da Universidade de Kiel (Alemanha).

\begin{tabular}{|l|l|l|l|l|l|}
\hline VERITAS & Porto Alegre & v. 51 & n. 1 & Março 2006 & p. 133-146 \\
\hline
\end{tabular}


em si mesma e desenvolve todas as medidas de superação da crise internamente, mediante a análise da própria situação de crise, pela via da autocrítica e do auto-esclarecimento da razão humana.

(2) A moderna filosofia política da superação interna de crises é, do início ao fim, uma teoria do uso racional do poder. O processo da instituição de ordem é desenvolvido como seqüência de constelações do poder e da razão. No início, encontra-se a percepção de que os seres humanos são vulneráveis e sujeitos a um regime de escassez. Eles empreendem esforços desesperados para se afirmar nesse estado de desproteção e insegurança natural. Armam-se, acumulam poder, aumentam seus investimentos em defesa. Mas todo o planejamento racional não nos ajuda muito. A razão tateia e acaba caindo na armadilha da prudência: quanto mais coerentemente ela executa seu programa de segurança privada, tanto mais inseguras tornam-se as circunstâncias da vida. A análise desse paradoxo da racionalidade leva a razão a perceber o caráter racionalmente preferível da cooperação. Essa, porém, precisa ser organizada de maneira que resista à exploração, exige dos indivíduos que desistam do exercício privado do poder e, ao mesmo tempo, precisa dotar cada um da garantia efetiva de que essa desistência de fato ocorrerá reciprocamente. Isso coloca em jogo a autoridade estatal, que zela pelo cumprimento das regras de cooperação e proporciona eficácia à cooperação, mediante o poder absoluto da razão superior.

(3) Ninguém descreveu de maneira mais impressionante essa trajetória, que se estende da razão impotente dos habitantes do estado de natureza até à razão poderosa do Estado, dispensador de segurança, do que o herói fundador da filosofia política da Idade Moderna: Thomas Hobbes. Mas, antes de me dedicar às três constelações de razão e poder contidas em sua história da criação do mundo político, a partir da necessidade de conservação dos egoístas racionais, gostaria de abordar, com brevidade, a relação entre poder e razão no pensamento político de Maquiavel.

\section{Potência de ação e instituição de ordem}

(4) A filosofia política da época anterior a Maquiavel considerava o poder como instrumento indispensável de domínio que estava sempre inserido num marco de ações e âmbito de tarefas definidas pela ética e empurrava o poder, que empregava a violência, para a periferia do mundo político, reservando-o para situações-limite, às quais não se podia aplicar o interesse da teoria orientada pelo bem comum. Na incipiente filosofia política da Idade Moderna, entretanto, a situaçãolimite passa para o centro da atenção teórica. A situação-limite torna-se o modelo do mundo político, a partir do qual se pode depreender a gramática da ação política. No famigerado "espelho do príncipe" deformante, publicado por Maquiavel em 1513, O príncipe, esboça-se um padrão de ação política que visa unicamente à continuação e intensificação da potência de ação, afirma sem reservas o poder, eleva a maximização do poder à condição de fim em si e remove, de maneira coerente e completa, o elemento de tabu da violência. 
(5) O príncipe de Maquiavel não se encontra mais na obrigação de organizar uma coletividade justa e administrá-la bem. Ele é dissociado de toda vinculação ética e só quer saber ainda de seu interesse privado no exercício do poder. O domínio perde seu caráter de ofício ético, tornando-se um bem muito cobiçado do qual todo o mundo gostaria de se apoderar. E Maquiavel torna-se o conselheiro político dessa nova geração de políticos, projetando uma técnica de domínio inteiramente despreocupada com exigências éticas em cujo centro se encontra o incremento da potência de ação (cf. Kersting, 1988 e 1998). Esse programa de autoconservação política, que gira em torno da acumulação de poder, será depois generalizado por Hobbes, em sua teoria do estado de natureza, convertendo-se num padrão de comportamento humano universal.

(6) O significado mais profundo dessa figura de príncipe, porém, só fica claro, quando associada com a doutrina de Maquiavel acerca da instituição de uma constituição e do ciclo das formas constitucionais exposta nos Discursos. Para o republicano Maquiavel, a destruição de um Estado sempre transcorre de cima para baixo. A corrupção se infiltra descendo das alturas dos regentes e percorrendo os degraus da hierarquia social até chegar aos baixios do povo. Ela começa com o definhamento da virtù entre os poderosos, da classe política, dos detentores de cargos, e infecta a seguir a coletividade inteira. A comunidade política é desagregada pela formação de partidos, pelo egoísmo grupal e pela busca cobiçosa do poder privado. O bem comum perde sua compromissividade, que orientava a ação e determinava o comportamento; ele torna-se, junto com os outros valores da forma de vida civil, uma máscara ideológica com a qual o interesse particular procura se camuflar. A figura republicana da virtù, que tem sua raiz subjetiva na atitude cidadã, no bíos politikós, e seu sustentáculo objetivo nas leis, costumes e instituições políticas, dá lugar à fortuna, que floresce no vácuo de poder. Com o domínio da fortuna tem início o caos. A razão do poder, que domesticou a ambizione, através de leis e instituições políticas, perverte-se ao virar desrazão da violência com a qual o ambicioso interesse privado cobre a coletividade e a arruína em termos políticos e morais.

(7) Entretanto, esse estado de anomia e desordem não é duradouro. Assim como o brilho da ascensão sempre permanece sombreado pelo temor da decadência, da mesma maneira cresce, em meio ao caos e à ruína moral, a esperança de conversão e salvamento. Corresponde à lógica da concepção cíclica da história esposada por Maquiavel, que as crises sejam consideradas chances de inovação política. Elas oferecem a um homem ambicioso e politicamente talentoso a oportunidade de dar forma à sua vontade e de plasmar o mundo informe, erigindo um monumento para si mesmo, através de uma grande obra de estabelecimento de ordem política.

(8) A renovação política é necessariamente obra de uma grande personalidade, de um homem que dispõe, em grau extraordinário, de habilidade política, de virtù; é obra de um uomo virtuoso, pois "um grande número de cabeças não é apropriado para levar ordem a um Estado" (Maquiavel, 1977, p. 37). Independentemente de a situação politicamente aflitiva ter sido provocada por uma desinte- 
gração interna da coletividade ou ter surgido por causa de uma guerra perdida ou pela invasão de potências estrangeiras, o povo não pode libertar-se ele próprio de sua miséria, não pode refrear-se a si mesmo institucionalmente e dar-se uma forma política. Há necessidade da personalidade de um líder carismático que, no início, conclame o povo severamente à ordem e, depois, o eduque politicamente, mediante seu próprio exemplo. Assim como a coletividade arruinada precisa do indivíduo eminente para poder se erguer, da mesma maneira o uomo virtuoso necessita de um campo de ruínas, em termos políticos e morais, para poder desenvolver da melhor maneira e empregar gloriosamente sua genialidade política e seu talento construtivo.

(9) O uomo virtuoso é um renovador político, instituidor de ordem, legislador e educador político por seu exemplo e sua ação. Primeiramente ele pacifica a coletividade e cria ordem nela, ao "reprimir a ambição excessiva e a perversão dos poderosos com poder irrestrito e extraordinário", e depois desperta virtù e atitude política nas pessoas (Maquiavel, 1977, p. 143). Ele não só se distingue pela capacidade de ser desconsideradamente coerente na conquista e no emprego dos meios de exercício do poder na criação de ordem política, mas também precisa demonstrar que possui competência nomotética e imaginação político-constitucional. O que é extraordinário nele, entretanto, é, principalmente, que ele próprio, junto com a consolidação institucional da ordem de domínio, vincula o poder irrestrito da fase inicial, mediante formas constitucionais, compreendendo-a como situação excepcional que precisa dar lugar à normalidade política da coletividade estabilizada por leis, instituições e espírito de cidadania. O poder do uomo virtuoso tem uma qualidade diferente do poder dos líderes partidários, que jogam lenha na fogueira da crise, porque usam a desordem para perseguir sem inibições seus interesses egoístas. Ele não é poder privado destruidor, e sim poder de configuração política. Como poder da ordem construtiva, ele é a razão política externa, que domestica as ambizioni desenfreadas e reprime paulatinamente o domínio da fortuna, do acaso cego e imprevisível.

(10) O uomo virtuoso, o príncipe nuovo, o qual apanha o poder que jaz na estrada e funda um novo domínio, corresponde estruturalmente ao fundador do Estado do moderno direito natural que submete todos à sua vontade e supera, assim, o estado de natureza, o estado de uma virtual guerra de todos contra todos. Mas após o término do estado de anomia, depois de ocorrido o reordenamento político, o uomo virtuoso, o prudente ordinatore d'una repubblica (o organizador prudente de uma república), precisa devolver às pessoas o Estado instituído e distribuir o poder prudentemente entre as forças da sociedade. Só nesse caso sua obra política vai sobreviver a ele, e só assim a coletividade ou república terá solidez e durabilidade e ele adquirirá glória histórica.

(11) O arco de atividades de ordenamento político do inovador, descrito em termos de tipo ideal, se estende, portanto, desde o domínio do krátos até ao domínio do éthos, desde a violência, como meio extraordinário de exercício do poder, em épocas de crise, até às instituições republicanas controladoras do 
poder, as buoni ordini. O objetivo é consolidar a ordem criada de tal maneira que ela se torne capaz de se manter a si mesma. Para Maquiavel, a melhoria política de uma coletividade leva da necessidade de manutenção por outrem à capacidade de automanutenção. A organização do domínio deve tornar a república independente da virtù extraordinária da grande personalidade do fundador. Maquiavel não deixou dúvida de que os passos do desenvolvimento da coletividade, para deixar a crise atrás de si, tomam o caminho de uma emancipação da comunidade civil em relação à tutela do herói fundador. Para Maquiavel, as repúblicas são capazes de automanutenção no mais alto grau, razão pela qual ele as prefere a outras formas de organização do domínio. Na capacidade de tornar uma coletividade capaz de vir a ser uma república, manifesta-se a qualidade inovadora do uomo virtuoso. As repúblicas têm poder próprio e estão direcionadas para sua própria continuidade: elas são a virtù objetivada de seu herói fundador. A habilidade de dominar a fortuna, que tinham seus fundadores, se transmitiu a elas na forma das leis e instituições que criaram, por um lado, e do espírito comunitário dos cidadãos, por outro, de sorte que agora as repúblicas conseguem se impor, com força e habilidade próprias, contra os ataques de fortuna. "A única constituição estatal permanente é aquela em que a lei é a regente por si mesma e não depende de uma pessoa particular", reza o credo republicano jusfilosófico da teoria do direito de Kant (AA, v. VI, p. 341). Exatamente essa idéia transparece também no credo republicano de Maquiavel.

\section{A antropologia de Hobbes I: razão e planejamento do futuro}

(12) O sistemático Hobbes vai muito além do pragmático Maquiavel. Aquilo que o intrépido conselheiro de príncipes ainda formula como regra de prudência política, para detentores do poder, converte-se em princípio antropológico geral para o filósofo científico e bem mais radical. O ser humano como tal é entendido como um ser determinado pelo poder, que, como subjetividade atuante, se define unicamente pela categoria do poder, que depreende os critérios de sua autoavaliação e de sua avaliação dos outros, de seu encontro com o mundo e de sua existência social, tão-somente da lógica e economia do poder. Em consonância com isso, para Hobbes, a razão é essencialmente competência de planejamento e consciência prática do futuro. A razão capacita para a previsão, para a antecipação de conseqüências, para ações preventivas. Sua especialidade são os meios, não os fins. Ela busca meios, inventa meios, seleciona prudentemente entre os meios dados, mas não avalia fins, não rejeita, ao contrário da razão kantiana ou da razão comunicativa da ética do discurso, fins que não possam ser universalizados. No pensamento de Hobbes, os fins estão, como leis do movimento, inscritos no ser humano natural ou então são adquiridos em concordância com essas leis do movimento, as concretizando e diferenciando.

(13) A tarefa da razão só pode ser a de administrar a consecução dos fins, e ela consegue isso principalmente com base numa tríplice função ou atividade de 
distanciamento. Em primeiro lugar, com base no distanciamento da presença da situação de percepção e necessidade [no sentido de carência] e da descoberta do futuro. Em segundo lugar, com base no distanciamento do caráter factual da ação e da descoberta do elemento da opção. E em terceiro lugar, mediante o distanciamento reflexivo, que é o que possibilita ao ser humano romper com o encantamento do imediato e relacionar-se consigo mesmo, distinguindo de si mesmo seus objetivos e fins, tanto aqueles que se apresentam com urgência natural quanto aqueles que são mediados e adquiridos socialmente. Mediante essas funções ou atividades da razão, torna-se possível que o ser humano organize suas preferências e submeta a realização de seus interesses a um cálculo prudencial que busca o aumento da utilidade. A razão de Hobbes é a de um calculador focalizado na maximização que, com base numa estimativa das conseqüências instruída pela experiência e com vistas a situações futuras de necessidade ou carência, efetua cálculos da relação entre custo e benefício, no tocante a todas as opções de ação disponíveis para apurar qual é a estratégia mais bem-sucedida e calcular qual é a melhor ação.

\section{A antropologia de Hobbes II: acumulação de poder}

(14) No espaço da ação social, a razão instrumental se torna estratégica. Os sujeitos atuantes se encontram uns com os outros apenas como meio que promove ou obstrui os próprios interesses. Por conseguinte, a troca e a concorrência competitiva mostram-se como as duas formas fundamentais de interação da racionalidade estratégica. Por isso, o interesse fundamental das pessoas se volta para modos de comportamento que assegurem sucesso no marco dessas formas de interação. E esse modo é principalmente a estratégia de incremento do poder, pois o poderoso consegue decidir a concorrência a seu próprio favor e determinar os custos em situações de troca.

(15) O poder serve à ampliação da liberdade de disposição, ao aumento das opções de ação. A preocupação com o poder é a preocupação com a maximização dos meios de exercício do poder; ela quer uma descontingencialização das circunstâncias da vida e visa a uma despotenciação preventiva das contingências naturais e sociais, pretende minimizar as imprevisibilidades, os distúrbios e as interferências que sabotam a felicidade e impedem se alcançar e consolidar um estado de satisfação abrangente. O poder quer reduzir a imprevisibilidade do futuro, busca a desfatalização, quer tirar o poder do destino.

(16) Essa busca do poder, por parte da razão providencial instrumental, porém, leva o ser humano a um dilema: embora o poder não seja um fim em si mesmo, a busca do poder é necessariamente auto-referencial. O poder não se esgota no serviço à carência; ele vai além da função de disponibilização dos meios, pois sempre precisa querer também a si próprio, precisa estar interessado em sua própria consolidação e continuidade. A lei da racionalidade finalística, que a permeia inteiramente, se inverte: os fins, objetivos e desejos da pessoa passam para o 
segundo plano, e o próprio poder transforma-se em fim. Nesse tocante, o poder se assemelha ao dinheiro, que segundo a famosa fórmula geral do capital, proposta por Marx, torna-se sujeito de um processo de autovalorização e, como mais-valia, se desfaz de si mesmo como valor originário: também o poder, depois de envolvido no processo de acumulação, torna-se sujeito e alvo desse processo, se desfaz, como mais-poder, incessantemente de si mesmo como poder originário e potencia a si próprio (Marx 1968, p. 169s.).

\section{O estado de natureza - um dilema da racionalidade}

(17) A tese central da concepção de estado natural de Hobbes é a seguinte: o estado de natureza é um estado de guerra. A satisfação das necessidades humanas ocorre sob a condição de uma dupla e irrevogável escassez. Tanto os próprios bens desejados quanto os meios necessários para sua aquisição presente e futura são escassos. Por isso, os seres humanos são concorrentes em duplo sentido: concorrem uns com os outros pelos bens visados e concorrem uns com os outros pelo poder. Em conseqüência, a satisfação das necessidades humanas se encontra sob a lei de interesses conflitantes: sob a condição da escassez dos bens e do poder, os desejos objetais direcionados para os bens e os desejos de poder entram em colisão. A escassez gera conflitos. No estado de natureza, os concorrentes estão, em princípio, dispostos ao uso de violência, tornando-se inimigos. A tendência à hostilização é estruturalmente inerente ao estado de natureza. É preciso contar com o pior e antecipar-se ao uso de violência por parte dos outros.

(18) "Homo homini lupus" ["o ser humano é um lobo para o ser humano"] (Hobbes, 1966, p. 59). Esse famoso dito de Hobbes torna-se compreensível frente ao pano de fundo do estado de natureza. Aqui não se está falando de uma natureza pulsional de caráter irracional e lupino, de uma avidez obsessiva pelo poder, e sim das estratégias preventivas da razão instrumental, da desconfiança ofensiva disposta a recorrer à violência. O ser humano é um lobo para o ser humano, porque o ser humano é um ser providencial e racional. Independentemente de contar entre os moderados ou os agressivos, entre os piedosos ou entre os maus, com base em seu caráter e temperamento contingentes e individuais, ele precisa, já que está interessado em sua própria conservação e possui uma razão, exercitar-se no comportamento lupino e empregar violência antecipando-se à violência alheia. Entretanto, essa estratégia da acumulação de meios de exercício do poder e armamento é tão irracional quanto necessária. O estado de natureza acarreta a perversão da razão; seu design faz com que a racionalidade produza inevitavelmente o oposto de si mesma.

\section{A preferencialidade racional da cooperação}

(19) Essa situação aporética leva a razão a pensar. Ela percebe que o estado de guerra só poderá ser superado, se os indivíduos sujeitarem seu comportamento a regras de cooperação racional e pacificação racional. Agora, no segundo pata- 
mar do desenvolvimento, a razão instrumental assume a forma de um conselheiro geral para egoístas racionais. Ela desenvolve um programa de regras para egoístas, formula prescrições e esboça uma estratégia de cooperação que, face às circunstâncias naturais, precisa ser colocada sob a condição da racionalidade da reciprocidade e exige um acordo contratual de todos como pessoas livres e iguais.

(20) Contudo, essa percepção da razão a respeito da irracionalidade da concorrência natural e desregulamentada e da preferencialidade racional da cooperação não deve ser entendida equivocadamente. As circunstâncias antropológicas dadas não mudam com o abandono do estado de natureza. O modelo de cooperação não é pura e simplesmente hostil à concorrência. A defesa da cooperação não é expressão de um temperamento sensível, ávido de harmonia que não consegue suportar a robustez da competição, o clima agreste da concorrência e as tensões do antagonismo de interesses. O modelo de cooperação social de maneira alguma nega a eficiência da competição e está perfeitamente ciente dos múltiplos progressos civilizacionais diretos e indiretos devidos unicamente à concorrência organizada nos moldes do mercado - de interesses, capacidades e idéias. Se a competição fosse sufocada no mingau adocicado da harmonia, todo potencial inovador se atrofiaria, e o desenvolvimento social estagnaria; a sociedade empobreceria rapidamente e teria de cancelar todos os projetos civilizacionais que impliquem custos.

(21) Entretanto, a percepção da preferencialidade racional do comportamento cooperativo não é suficiente. Na terceira fase, a razão precisa aprender que deve ir além da formulação das prescrições de cooperação racional e da urgente recomendação prudencial de buscar a paz e cooperar. Ela se dá conta de que não se pode aconselhar a ninguém que tenha uma atitude cooperativa e pacífica, se não há garantia de que todos alcancem a autodisciplina associada à atitude cooperativa e pacífica, se cada um não puder ter certeza da fidelidade contratual dos outros. Ela deriva dessa percepção a tarefa de transformar as circunstâncias de tal maneira que se garanta uma observância geral das regras da paz da razão natural e, por conseguinte, o indivíduo possa fazer, sem correr riscos, o que sua razão lhe prescreve no interesse de garantir sua vida e promover sua felicidade. E ele só pode fazer isso, sem correr perigo, se um poder coercitivo irresistível conferir eficácia às prescrições da razão, que Hobbes também designa como "justiça natural", e assegurar o cumprimento de todos os contratos. "A mera concordância ou o mero acordo quanto a uma associação, sem a instituição de um poder comum que guie os indivíduos mediante o temor da punição, não é, pois, suficiente para a segurança necessária ao exercício da justiça natural" (Hobbes, 1966, p. 127). O interesse vital numa situação pacífica e numa vida satisfatória só pode ser realizado ao preço do estabelecimento de um sistema eficaz de coerção, justamente do Leviatã.

(22) "Homo homini lupus". O ser humano é um lobo para o ser humano, porque, sob as condições do estado de natureza, sua razão exige dele o desenvolvimento e emprego de uma estratégia de auto-afirmação disposta ao recurso à violência e de desconfiança ofensiva. As condições do estado de natureza, porém, 
são circunstâncias vitais de uma espécie tal que todo o necessário esforço da razão, por parte dos indivíduos, leva ao resultado aporético de uma piora incessante da situação geral para todos. A máxima racionalidade subjetiva produz máxima irracionalidade objetiva. Ora, a mesma prudência que, sob as condições do estado de natureza, se torna uma armadilha para o ser humano, já que, mediante os esforços de sua racionalidade subjetiva, ele piora inevitavelmente o estado objetivo e, assim, também suas próprias condições de vida, indica-lhe também uma saída para esse dilema da racionalidade: a cooperação com todos os outros, o contrato para a fundação do Estado. O ser humano não é um lobo para o ser humano tout court: é só no dilema de racionalidade do estado de natureza que ele se mostra como tal, só no clima da concorrência competitiva. No marco de uma situação cooperativa, contudo, ele se mostra como parceiro do progresso civilizacional; cooperando e ajustando a perseguição dos próprios interesses ao conjunto de regras pacificador do Estado, o ser humano é um deus para o ser humano - "homo homini deus" (Hobbes, 1966, p. 59).

(23) Essas duas fórmulas antropológicas de Hobbes oferecem uma condensação impressionante da insociável-sociável tensão básica do indivíduo moderno. Elas expressam, com o máximo de ênfase, a distância de racionalidade entre as estratégias da concorrência absoluta e da cooperação. Decisivo, porém, é que a negatividade da fórmula, que fala do lobo, e a positividade da fórmula, que fala do deus, se devam à mesma razão humana. Só que, como razão do ser humano-lobo, essa razão é reativa, respondendo à situação de vida dada do estado de natureza, ao passo que, como razão do ser humano-deus, ela torna-se uma razão construtiva e criativa, substituindo as condições do estado de natureza por circunstâncias vitais de feitura própria, especificamente humanas, e criando, com isso, os pressupostos para a paz, a felicidade individual e o progresso civilizacional. O ser humano é um deus para o ser humano, ao repetir, junto com seus semelhantes, o ato divino da criação e criar para si um mundo artificial, uma segunda natureza, na qual, diferentemente do mundo natural, da primeira natureza, o ser humano tem a possibilidade de viver.

\section{6 poder absoluto de ação e decisão do Estado}

(24) O Estado é a condição sob a qual a percepção humana da preferencialidade racional da cooperação pode tornar-se atuante. Ele dota a razão cooperativa de poder e lhe proporciona validez real. E visto que, sem ele, só existiria a desrazão do estado de natureza, ele próprio é a realidade da razão. Só que, segundo Hobbes, ele só pode garantir a realidade da razão, se possui poder absoluto, não sendo limitado no exercício de seu poder, nem por regras do direito natural, nem por inalienáveis direitos individuais básicos, nem por princípios de justiça nem por um conjunto de regras constitucionais que moderem o domínio. O lugar da razão política não reside num conjunto de regras jurídicas preexistente e imposto ao poder, e sim na vontade absoluta, não limitada por quaisquer princípios precedentes. No absolutismo hobbesiano, o domínio político não sossega numa constitui- 
ção; a razão política não se consolida numa obra nomotética que coordene autocraticamente a vida dos cidadãos e em relação à qual o detentor do poder possa passar para o segundo plano. O Leviatã não pode sair da sombra do estado de natureza. A lógica decisionista da situação de seu surgimento marca toda a sua ação. Ele vive em permanente temor da guerra civil, da recaída na anarquia. Sempre vê seu domínio contestado pela dinâmica conflituosa do estado de natureza. Ele é desconfiado, sempre cauteloso, presume que inimigos o estejam espreitando, divisa em cada cidadão um risco para a ordem, precisando, por isso, reservar para si a competência última de decisão, em todos os assuntos que tenham a ver com a ordem política. A normalidade é vedada ao poder estatal; ele nunca pode tornarse invisível na rotina cotidiana da aplicação de regras situacionalmente prudencial. Como o Deus voluntarista da Escolástica tardia, o Leviatã determina sozinho o que deve ser tido como justo e injusto. Como o Deus voluntarista da Escolástica tardia, ele se furta de toda ordenação e moderação do poder; cabe-lhe a potestas absoluta [poder absoluto].

(25) Uma organização do domínio com divisão de poderes empurraria o Estado de volta para o estado de natureza. Por isso, para Hobbes, a doutrina do regimen mixtum [regime misto] e da divisão de poderes está "óbvia e diretamente direcionada contra a essência de um Estado" (Hobbes, 1976, p. 248). Ela é uma heresia, em termos de ordem política, e tem de ser reprimida por um Estado interessado em sua própria saúde da mesma maneira como todas as outras "doutrinas errôneas" incompatíveis com a natureza do Estado e que o impeçam de cumprir seu fim de proporcionar paz e segurança: p. ex., a opinião de que, no Estado, o ser humano como tal teria um juízo moral próprio e um direito de expressá-lo e colocá-lo acima das determinações estatais, ou de que também o soberano estaria, assim como todo e qualquer súdito, sujeito a suas leis, ou de que o direito de propriedade teria validade irrestrita e estaria, por isso, subtraída a toda e qualquer disposição, por parte do Estado, ou, finalmente, que haveria a possibilidade de um soberano se tornar tirânico e poderia, nesse caso, ser destituído ou morto (cf. Hobbes, 1976, cap. 26).

(26) O argumento da teoria da soberania do poder absoluto adquire uma versão bem mais sofisticada e exigente, quando Hobbes o emprega contra o direito natural e o constitucionalismo, quando não visa fundamentar a limitação institucional do poder, e sim a impossibilidade de uma vinculação da ação estatal a acordos contratuais, normas jusnaturais de justiça, direitos humanos, princípios constitucionais ou até mesmo a suas próprias leis.

Todas as leis, escritas ou não, têm necessidade de uma interpretação. A lei da natureza, que não é escrita, embora seja de fácil acesso aos que, sem parcialidade ou paixão, fazem uso de sua razão natural, deixando, portanto, sem desculpa seus violadores, tornou-se agora apesar disso, devido ao fato de haver poucos, ou talvez ninguém, que em alguns casos não se deixem cegar pelo amor de si ou qualquer outra paixão, a mais obscura de todas as leis, e por isso é a que tem mais necessidade de intérpretes capazes. Quanto às leis escritas, se forem breves, facilmente serão mal-interpretadas por causa da significação diferente de uma ou duas palavras; se forem longas, tornar- 
se-ão tanto mais obscuras por causa da diversidade de significações de muitas palavras. De modo que nenhuma lei escrita, quer seja expressa em poucas ou em muitas palavras, pode ser bem-compreendida sem uma perfeita compreensão das causas finais para as quais a lei foi feita, e o conhecimento dessas causas finais está com o legislador. Para este, portanto, nenhum dos nós da lei pode ser insolúvel, seja achandolhe as pontas e por aí desatando-o, seja fazendo quantas pontas lhe aprouver (como Alexandre fez com sua espada ao nó górdio), através do poder legislativo, coisa que nenhum intérprete pode fazer (Hobbes, 1976, p. 211 [p. 171 da edição brasileira, traduzida por João P. Monteiro e Maria B. Nizza da Silva]).

O argumento em favor da necessidade de um soberano absoluto, de um poder supremo incontestado e incontestável, é um argumento em favor da necessidade de um intérprete último que possa dar a suas interpretações validez e eficácia, em última instância, em favor de um tomador de decisões último, que ponha fim a disputas de opiniões e interpretações e resolva autoritativamente o debate.

(27) A prudência estatal do Leviatã consiste em evitar a guerra civil. E a guerra civil confessional ensinou a Hobbes que dotar a prudência estatal do monopólio do poder não é suficiente para cumprir a finalidade da pacificação. Ela necessita, além disso, do monopólio da interpretação e definição. Precisa fixar qual é o significado das palavras e definir o que é tido como verdade e o que não pode ser admitido como verdade, pois a guerra civil confessional foi uma guerra de ideologias, uma luta de verdades concorrentes pelo poder absoluto, uma luta de interpretações e significados. Por isso, uma estratégia que vise evitar a guerra civil precisa conter a disposição sobre o significado de conceitos normativos e religiosos relevantes para a ação. Entretanto, como mostra a citação acima, o argumento da necessidade de uma fixação autoritativa última das interpretações e palavras vai muito além disso, pois não quer apenas mostrar a imprescindibilidade de submeter a religião, filosofia e literatura às definições estatais da verdade, mas também fundamentar a impossibilidade prática de um condicionamento constitucional, qualquer que seja concretamente, do domínio estatal.

(28) O argumento se baseia em duas teses da filosofia da linguagem. A primeira é a tese a respeito da carência de interpretação de normas gerais, que também se pode designar como tese do decisionismo de aplicação. Isso quer dizer que, a partir de leis, não se podem obter juízos relacionados a casos particulares pela via da dedução lógica. Sem determinações que selecionem entre significados concorrentes das leis, ou ampliem os significados transmitidos dos conceitos legais, não é possível a passagem do nível de generalidade da fórmula legal para o nível concreto do caso de aplicação. A razão disso deve ser buscada na natureza dos conceitos legais, que têm de ser necessariamente gerais e sempre possuem um leque de significados situado em torno de um centro de significado, e esse leque possibilita interpretações concorrentes. Visto, porém, que a questão do significado não pode ser mantida na suspensão não-compromissiva de opiniões rivalizantes, pois as leis pretendem oferecer orientações determinantes da ação, é preciso decidir: a lei só pode adquirir relevância prática no meio da decisão, e não já no meio do conhecimento. 
(29) A segunda tese é a do nominalismo. Ela corrobora o resultado da primeira tese e junta sua voz em alto tom à conclamação da necessidade de decisão autoritativa. Designa-se como nominalismo a posição da teoria da linguagem e do conhecimento que nega a existência de objetos universais e de uma recta ratio [razão reta] responsável pelo conhecimento da universalidade. Junto com o declínio do conceito tradicional de natureza, desaparecem da natureza também as entidades universais e desaparece, por igual, a razão reta, que originalmente estava determinada pela natureza para o conhecimento de sua própria essência. Nesse mundo esvaziado de entidades só restam indivíduos, coisas avulsas. E os conceitos adquirem seu significado, não através de um objeto universal a eles associado, e sim mediante a abstração de características. A destruição nominalista do mundo da moral natural tem, por essência, efeitos particularmente dramáticos. Junto com ele desaparece o fundamento objetivo de significados dos princípios do direito natural. Surge forçosamente um objetivismo de significados que produz um caos moral.

(30) A categoria filosófica de Hobbes é atestada pelo fato de ele explicitar o estado de guerra, não só como cenário de conflito psicológico-racional, mas também como caos de significado, que precisa ser organizado da mesma maneira como o mundo da ação. E ele só pode ser organizado, se o vácuo de objetividade for preenchido por decisões instituidoras de significado, se o lugar da natureza moral objetiva, o qual foi a pique, for tomado por um conjunto de regras artificial do Estado que seja compromissivo para todos e determine o que é "justo" e "injusto", "meu" e "teu", "compromissivo" e "inválido". Visto que os seres humanos não têm condições de conferir aos conceitos normativos fundamentais de orientação de seus discursos morais e políticos um significado objetivo, apelando a uma natureza responsiva, assim como tampouco têm condições de chegar a um acordo, na prática consensual, quanto a um significado de compromissividade geral, eles precisam submeter-se às decisões de um criador de significados.

\section{Observação final}

(31) Para Hobbes, existe uma disjunção completa entre estado de guerra e domínio absoluto: ou anarquia ou domínio absoluto - tertium non datur [não há uma terceira opção]. Essa tese parece pouco plausível, e também não pareceu plausível a seus contemporâneos e seguidores filosóficos: por que alguém que, como Hobbes, considera inaceitável a opção pela anarquia e compartilha a percepção de que o estado de natureza precisa ser abandonado teria de se fixar na posição do Estado absolutista? Ao passo que Hobbes vê no domínio absoluto uma condição tanto necessária quanto suficiente da paz social, o contrário parece muito mais plausível, a saber, que o domínio absoluto não é uma condição nem necessária nem suficiente de uma coexistência livre de violência. Ela não é necessária, porque também um domínio moderado, constitucionalmente vinculado, pode assegurar os efeitos desejados da superação do estado de natureza. E não é suficiente, porque não há garantia de que o detentor do poder absoluto não vá trans- 
formar-se numa autoridade terrorista, que, como lobo restante, causa estragos entre os cidadãos sem direito e sem poder. Por isso, os teóricos do contrato posteriores acusaram o contrato hobbesiano da desistência mútua do poder e do direito de ser, não só ilegítimo, mas também irracional: ser de opinião de que os habitantes do estado de natureza o fechariam significaria, em última análise, "considerar as pessoas tão bobas que se esforçam para evitar o prejuízo que pode surgir para elas por causa de martas ou raposas, mas ficam felizes e até consideram segurança serem devoradas por leões" (Locke, 1977, p. 258).

(32) A história pós-hobbesiana da política e das idéias políticas é uma história da domesticação do Leviatã. Sua liberdade de movimentos foi cerceada por grilhões institucionais das mais diversas espécies: sua natureza selvagem foi atenuada pela moral dos direitos humanos; e seu jeito resoluto de ser e de agir foi tolhido pela penosa maquinaria da busca de consenso das organizações democráticas. O Estado moderno perdeu poder, mas ganhou enormemente em termos de competências; afinal, entrementes nós o tornamos responsável por todas as nossas circunstâncias de vida. Programas de tarefas do Estado de direito e do Estado social da mais diferente espécie fazem com que se esqueça o superador do estado de natureza. Por trás do ocupadíssimo realizador estatal de valores de nossa época, quase não se pode perceber mais a silhueta do deus mortal que infunde medo. Por isso, tendemos a perder de vista a lição antropológica que o Leviatã nos ensinou, uma lição que continuará sendo verdadeira, enquanto viverem seres humanos e enquanto sua verdade encontrar, a cada novo dia, uma triste confirmação nas regiões do mundo nas quais todas as estruturas de estatalidade se afundam no lodaçal da corrupção e das guerras civis. Liberdade, igualdade, fraternidade essa é a tríade moderna dos valores políticos; eles constituem os princípios de nosso auto-entendimento moral e político. Mais fundamental, porém, é a segurança. Só se o Estado cumprir a promessa de segurança ele poderá dedicar-se à tarefa adicional de autodisciplinamento do Estado de direito e de assistência à vida do Estado social. Segurança, defesa das pessoas e de sua propriedade é sua incumbência originária.

(33) Os seres humanos são desprotegidos, vulneráveis de muitas formas e condenados, por natureza, a uma vida com medo. Se eles quiserem livrar-se do medo, se quiserem estar protegidos, ter segurança, precisarão construir segurança, edificar um dispositivo de proteção. Nós certamente não somos - como pensava Aristóteles - seres políticos por natureza, destinados a um modo de vida cidadão. Mas dependemos por natureza do Estado, e muito mais ainda quando vivemos na Idade Moderna, em que não há mais uma rede estreita de comunidades de familiares e vizinhos que ofereça proteção. A individualização torna urgente o Estado. O processo de modernização intensifica nossa dependência de funções de segurança desempenhadas pelo Estado. Entretanto, o Estado só pode cumprir essas funções de segurança, sob a condição da soberania territorial e da autodeterminação basal do Estado nacional. Mas a modernização está inevitavelmente associada à globalização, ameaçando, por isso, destruir as condições de êxito do cumprimento efetivo da função de segurança por parte do Estado. A globalização 
despotencia o Estado nacional, dificulta seu regime de segurança, solapa sua autoridade e corrói suas fronteiras. Os Estados do Ocidente são a usina de energia da globalização. Em seu ordenamento estatal, surgiram as formas de vida, modelos organizacionais, processos de tomada de decisões e visões de mundo que agora estão se disseminando de maneira uniformizadora pelo mundo. E tudo isso só pôde desenvolver-se nos Estados ocidentais, por disporem de estruturas efetivas de estatalidade. É de se temer que a globalização acarrete perdas em termos de política de segurança. Isso seria a ironia da globalização. As vítimas da globalização se vingam, ao importarem seus déficits de segurança para o Ocidente. No front pátrio do capitalismo conquistador do mundo, a estatalidade entra, então, em processo de erosão. Teríamos voltado mais uma vez ao início do Leviatã, mas sem a perspectiva de poder repetir a história de sucesso da fundação racional do Estado em escala mundial. As puras quantidades providenciariam que o estado de natureza, deficitário em termos de segurança, se tornasse o estado global duradouro.

\section{Referências}

HOBBES, Thomas. Vom Menschen - Vom Bürger. Hamburg, 1966.

\footnotetext{
—. Leviathan. Frankfurt/M., 1976.

—. Naturrecht und allgemeines Staatsrecht in den Anfangsgründen. Darmstadt, 1976a.
}

KANT, Immanuel. Gesammelte Schriften. Akademie-Ausgabe, Berlin, 1902 s.

KERSTING, Wolfgang (1988): Handlungsmächtigkeit. Machiavellis Lehre vom politischen Handeln, in: Philosophisches Jahrbuch 95.

\footnotetext{
—. Niccolò Machiavelli. 2. ed. München, 1998.

Thomas Hobbes zur Einführung. 2. ed. Hamburg, 2002.
}

LOCKE, John. Zwei Abhandlungen über die Regierung. Frankfurt/M., 1977.

MACHIAVELLI, Niccolò. Discorsi. Gedanken über Politik und Staatsführung. Deutsche Gesamtausgabe, Stuttgart, 1977.

MARX, Karl. Kapital I. Frankfurt/M., 1968. 